\title{
The translational significance of epithelial- mesenchymal transition in head and neck cancer
}

\author{
Christian A Graves ${ }^{1,2}$, Fadi F Abboodi ${ }^{1}$, Swati Tomar ${ }^{1}$, James Wells ${ }^{2}$ and Lucia Pirisi ${ }^{*}$
}

\begin{abstract}
Positive markers of epithelial-mesenchymal transition (EMT) in head and neck cancers complicate clinical management and are associated with reduced survival. We discuss recent translational discoveries in EMT and suggest additional actionable molecular pathways, biomarkers, and clinical agents.
\end{abstract}

Keywords: EMT head and Neck cancer; Snail; Slug; Biomarkers; TGF beta and Head and Neck cancer; EMT and HPV; Clinical trials in HNSC

\section{Introduction}

Squamous Cell Carcinoma of the head and neck (HNC) is a complex neoplastic disease that affects the face, cranium, and neck. Clinically, HNC has usually invaded vital aerodigestive tract anatomy at presentation, and often affects key sensory nerves in the peripheral nervous system. The worldwide incidence of HNC is estimated at greater than 550,000 new diagnoses per year accounting for 15-20 new cases per 100,000 individuals [1]. Despite extensive well-powered studies and the emergence of targeted therapy, 5-year survival rates in HNC remain at approximately 50\% [2]. This poor survival is likely due to the fact that local invasion, lymph node involvement and metastasis are often present at the time of diagnosis. The head and neck contain nearly 40 percent of the 800 lymph nodes present throughout the body making invasive disease a serious clinical concern [3].

\section{Review}

Local invasion and metastasis are associated with Epithelial to Mesenchymal transition (EMT) and hold negative prognostic value. Median 5-year overall survival (OS) rates in HNC have held steady at $50 \%$ but decline to $10 \%$ when local metastasis is present at diagnosis [4].

While differing slightly by anatomic site, local invasion in the ipsilateral field is present in $\sim 50 \%$ of $\mathrm{HNC}$ at

\footnotetext{
* Correspondence: lucia.pirisi-creek@uscmed.sc.edu

'Department of Pathology, Microbiology \& Immunology, University of South Carolina School of Medicine, Bldg. 1 Room B43 6439 Garners Ferry Rd, Columbia, SC 29208, USA

Full list of author information is available at the end of the article
}

diagnosis and contralateral and bilateral invasion approach $\sim 35 \%$ [3]. Figure 1 shows the stage at presentation of HNC by anatomic site: at all sites, HNC presents at either stage III or IV in at least $60 \%$ of the cases, and tumors of the nasopharynx, oropharynx/tonsil and glottis present at stage III or IV in over $98 \%$ of the cases. Therefore, these tumors carry a higher overall metastasis risk. Local invasion and extracapsular spread require extensive and complex resection and chemoradiotherapy $[3,5]$.

Genomic studies over the past decade have begun to dissect the complex underlying biology in HNC, which is often associated with tobacco and alcohol use. Furthermore, involvement of high-risk papillomavirus (HPV) as an etiologic factor in some tumors of the head and neck, first posited by Syrjänen and colleagues in 1983, has now been positively demonstrated [4,6-8]. The addition of HPV-surveillance by p16 staining and molecular testing has become commonplace in the work-up of these tumors, and cases of HPV-mediated disease are on the rise [9]. Despite ample evidence for the role of HPV in cancer development at genital and skin sites in humans, it has taken several decades to connect HPV with HNC [10]. Seminal studies of canine oral papillomatosis suggested a role for EMT in tumors of the oropharynx $[11,12]$. Like early observations in animals, models of papillomavirusmediated transformation in human cells demonstrated hallmarks of EMT including induction of spindle morphology [13]. In HNC, the molecular findings of basic science studies of EMT have culminated in an ongoing effort to translate this entity into targeted therapeutics. Perhaps the greatest leaps forward have occurred in the molecular 


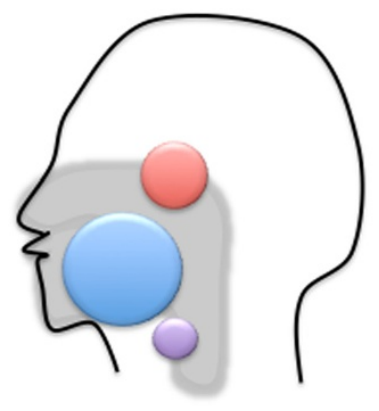

\begin{tabular}{|l|c|c|c|}
\hline Site & $\begin{array}{c}\text { Stage } \\
\text { III }\end{array}$ & $\begin{array}{c}\text { Stage } \\
\text { IV }\end{array}$ & $\begin{array}{c}\text { Stage III } \\
\text { or IV }\end{array}$ \\
\hline NPx & $62 \%$ & $38 \%$ & $100 \%$ \\
\hline L & $57 \%$ & $38 \%$ & $95 \%$ \\
\hline Ton & $47 \%$ & $37 \%$ & $84 \%$ \\
\hline FOM & $36 \%$ & $30 \%$ & $66 \%$ \\
\hline OPx/Ton & $55 \%$ & $43 \%$ & $98 \%$ \\
\hline Buc & $45 \%$ & $40 \%$ & $85 \%$ \\
\hline
\end{tabular}

\begin{tabular}{|l|l|l|l|}
\hline HPx & $36 \%$ & $24 \%$ & $60 \%$ \\
\hline SupGlot & $53 \%$ & $34 \%$ & $87 \%$ \\
\hline Glot & $56 \%$ & $44 \%$ & $100 \%$ \\
\hline SubGlot & $47 \%$ & $32 \%$ & $79 \%$ \\
\hline
\end{tabular}

Figure 15 -year overall survival of locally invasive disease by stage and anatomic site in HNC. Compiled from SEER data and AJCC database at cancer.org.

characterization of different types of HNC owing mainly to genomic, epigenomic, and transcriptomic sequencing studies [14-19]. In spite of this progress, EMT and the molecular underpinnings have not yet yielded robust clinical targets.

In this review, we discuss the translational relevance of EMT mechanisms in HNC and integrate these findings with the novel molecular picture emerging for this heterogeneous disease. We focus on the respective roles of viral infection and EMT in tumors of the head and neck; mechanisms of induction of EMT; the clinicopathologic outcomes associated with increased invasion; and how emerging therapies may take advantage of EMT determinants and markers.

\section{Translational hallmarks of EMT in embryogenesis and HNC}

EMT is a highly conserved process in development, cellular physiology and wound healing in every tissue compartment. First recognized in embryogenesis, the concept of EMT as a molecular program was suggested by Hay and Greenburg in 1982 [20]. This seminal description has been extensively refined and expanded, to include epithelial loss of anchorage dependence with the basal membrane, followed by fundamental alterations in genomic and epigenomic program execution in cellular polarity and motility [21,22]. Classic EMT-associated changes in protein expression coincide with loss of cell-cell adhesion complexes (e-Cadherin to $\mathrm{n}$-Cadherin shift, increased $\beta$-catenin transcriptional activity) and induction of mesenchymal cell adhesion molecules Vimentin (VIM),
Fibronection ( $F n$ ). Malignant cells also evade anoikis- or cell-microenvironment adhesion-dependent programmed cell death - by up-regulation of autocrine signalling from pro-survival factors epidermal growth factor receptor (EGFR), and transforming factor - beta (TGF $\beta$ ) which reduce Bax/Bak and Fas/Fas-Ligand-associated apoptosis. Loss of anchorage-dependent apico-basal orientation also corresponds with changes in cell morphology (i.e., stress $f$-Actin reorganization) and activation of GTPases (Cdc42 and Rac1), activation of planar polarity transcriptional programs (Pars/Crumbs, Snail, Slug), and degradation of the basement membrane via proteolytic enzymes (i.e., matrix metallo-proteinases, MMPs). These alterations allow cancer cells to induce peritumoral angio- and neuro-genesis, followed by metastasis and perineural spread, respectively. A variety of well-characterized types of EMT have been described. These include Developmental (Type I); Fibrosis and wound-healing (Type II); and oncogenic (Type III) [21]. However, advances in the understanding of the contributions from various highly conserved molecular pathways have blurred the lines between these three types. The general molecular underpinnings of EMT have been extensively reviewed elsewhere [21-24]. Here, we focus on the parallels across EMT types and the evidence for their involvement in HNC Cancer.

During gastrulation, the embryo undergoes specific modifications, among which is the establishment of stem cell polarity. This event is particularly pronounced during the early formation of the neural epithelium of the 
neural crest [23]. Within the context of the head and neck, these structures undergo profound differentiation leading to the formation of sensory and craniofacial structures derived from the neuroectoderm. In craniofacial development, molecular programming revolves around signals transduced by the central EMT modulator transforming growth-factor beta (TGF $\beta$ ). TGF $\beta$ family ligands are responsible for activating a symphony of developmental transcriptional programs [24]. A growing body of evidence suggests the importance of various homeobox transcription factors, polycomb repressive complexes, and stem cell differentiation factors in this dynamic process. In cancer stem cells, EMT activation promotes aberrant activation of developmental programs downstream of canonical Wnt, Notch, and Sonic Hedgehog (SHH) pathways (Reviewed in [24,25]).

Evidence for the involvement of these pathways in HNC development was first suggested from laser captured oropharyngeal biopsies, where increased expression of Frizzled1/3 (FRZ1/3) G protein coupled receptors (GPCRs), Dishevelled phosphoproteins (Dvl), and $\beta$ Catenin, (Wnt); Notch1/2 receptors, and Jagged ligand (Notch); and Patched (SHH) was observed [26]. In vitro, dysregulated Wnt/ $\beta$-Catenin was shown to increase cellular invasiveness and decrease anoikis, both hallmarks of EMT [27]. Analysis of fresh frozen specimens from 22 patients showed that a reduction in inhibitory Wnt-7a with a concomitant increase in frizzled 5 (FRZ5) and Wnt-5a correlated with reduced patient survival [28]. Markers of dysregulation of intrinsic feedback responses to increased $\beta$-Catenin - such as increased expression of Dickkopf-3 (Dkk3) - have also been demonstrated to correlate with poor survival and increased metastasis in HNC patients [29]. In addition, epigenetic modifications have been detected in patient-derived cell lines demonstrating hypermethylation of Dickkopf-1 (Dkk-1), secreted frizzledrelated peptides 1,2 , and 4 (SFRP1/2/4), and Wnt inhibitor factor 1 (WIF-1) [29-31].

\section{Studies of EMT in cancer-stem cells}

The discovery of epithelial stem-like cell drivers in cancer has revolutionized the search for the elusive Achilles heel in many neoplasms. HNC cancer-stem like cells have been isolated from patient-derived lesions and leveraged to identify novel therapeutic targets. Mattox and Von Hoff first observed the ability of poorly differentiated patientderived HNC cells to grow in soft agar in 1980 [32,33]. These observations took nearly two decades to mature into the current molecular theories that - in HNC - were suggested by Braakhuis, Leemans, and Brakenhoff [34].

A variety of stem cell molecular markers have been described in HNC including prominin-1 (CD133), the hyaluronic acid receptor CD44, Aldehyde-dehydrogenase 1 (ALDH1), and SOX2, Nanog, and OCT4, as well as basal keratinocyte marker cytokeratin 14 [35]. Importantly, CD133/OCT4/Nanog correlate with poor overall survival in a cohort of 52 oral carcinoma patients [36]. These developmental pathways synergize to drive EMT and invasiveness, are present in poorly differentiated lesions, and are linked to increased resistance to chemotherapeutic regimens. Figure 2 presents a synopsis of synergizing EMT and stem cell markers that have been linked to clinical course.

\section{EMT and local invasion, field cancerization, perineural invasion, and metastasis}

EMT remains a controversial pathobiological model in the clinical setting, and some question the validity of the concept outside of the confines of in vitro conditions and embryonal development [37]. Despite these dissenting opinions, EMT mechanisms are still regarded as the leading hypothesis for the process of cellular loss of adhesion and spreading, and many studies, including gene expression profiling of $\mathrm{HNC}$ readily demonstrate the expression of markers classically associated with EMT $[25,38,39]$. At diagnosis, it is believed that $2 / 3$ of $\mathrm{HNC}$ tumors harbor micrometastasis and locoregional invasion [40]. These prognostic indicators of enhanced morbidity are driven by a common feature of HNC lesions known as field cancerization. First suggested by Slaughter and colleagues, field cancerization is the development of a field of genetically altered cells in the context of a tissue. Within this altered field, the expansion of a patch of cells with increased proliferative and invasive potential gives rise to a tumor. This concept explains why cells in epithelia surrounding a tumor may present with some of the genetic and gene expression alterations found in the tumor cells $[41,42]$. It is not uncommon to find micro - primary and second primaries occupying cryptic sites (such as the base of tongue or tonsillar crypts) following additional diagnostic work-up in HNC. HPV-driven HNC is clinically differentiable from HPV-negative disease due to marked reduction in field cancerization, while nodal metastases are actually more frequently present at diagnosis $[43,44]$.

EMT drives local invasion principally via the mechanisms discussed above and several key transcription factors governing EMT have been demonstrated in metastatic disease. Among these, the most prominent molecular features include enhanced expression of the transcription factors Snail 1 and 2 (SNAI1 and SNAI2- aka Slug) as well as SIX1, TWIST, and ZEB 1 and 2. Many of these developmental transcription factors are hijacked from their normal roles in maintaining tissue homeostasis, and their functions center around the TGF- $\beta$ super family [25]. The importance of these transcription factors in head and neck development is reflected in animal studies, where mutant Snail and Slug result in craniofacial aberrations [45]. In keratinocytes, Slug plays a critical role in inducing the motile state in Type II EMT wound healing [46]. Decreases of 


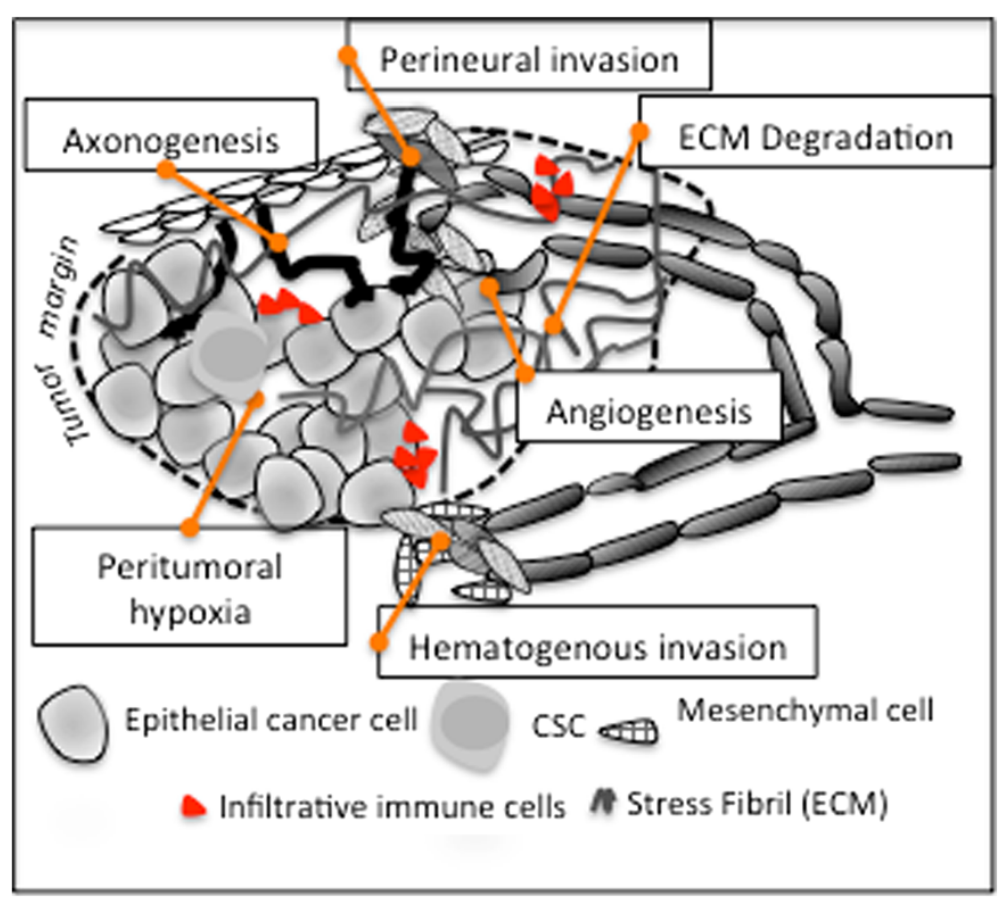

Figure 2 Following genotoxic insult (Mutations (for example: loss of tumor suppressor p53, cyclin-dependent kinase N2A (CDKN2A)); HPV infection, etc.) microenvironmental signals initiate and enhance pro-EMT pathology. Molecular signaling from the millieu promotes degradation of the extracellular matrix (ECM; Vimentin expression, matrix metalloproteinases (MMP) secretion); increased local and perineural invasion, angiogenesis, hyper mitotic features followed by hypoxia and intratumoral necrosis in parallel with tumor growth and metastasis.

downstream cell adhesion molecules and expression of mesenchymal markers are common features in many carcinomas and are not exclusive to HNC. Invasive HNC lesions often down-regulate E-Cadherin and up-regulate $\mathrm{N}$-cadherin, vimentin, and Slug [47]. This program is increasingly detected as an early and dynamic event in the evolution of the disease. Furthermore, the E- to Ncadherin shift is sentinel in the evolution of premalignant lesions to carcinoma in situ and neoplasia [48] (Table 1).

In support of these observations, Slug over expression has been recently found to correlate with increased lymph node involvement and higher TNM status in a study of 119 HNC [52]. Several immunohistochemical studies have demonstrated involvement of Snail in HNC; however, these results and their impact on prognosis have been conflicting. Yang et al. showed a correlation between augmented NBS1 and TWIST and Snail expression in tissue microarrays of HNC $[49,50]$. In a recent, well-designed study, $52 \%$ of cases stained intensely for Snail and this correlated with increased lymphovascular involvement, basaloid differentiation, and nodal metastasis [62]. These results are in contrast to other studies of archival specimens and related clinical data, which found no significant impact of Snail on patient prognosis [63]. The well-known oncogenic viruses Epstein-Barr Virus (EBV) has also been found to associate with enhanced EMT markers in HNC lesions [64] (Table 1).
Interestingly, perineural invasion - which is associated with a significant decrease of overall survival and increased metastasis - is enhanced in pro-inflammatory microenvironments (i.e., elevated cytokine/NFK $\beta$ activation) and in invasive disease [51]. The mechanisms of classically defined Type III EMT and perineural spread and invasion are distinct, but have some areas of overlap. For example, a likely player in perineural invasion is the neurotrophin tropomyosin-related kinase (NTRK2 aka TrkB) which signals downstream of brain derived neurotrophic factor (BDNF) [65]. TrkB has been demonstrated to be a key regulator of EMT in HNC and TrkB overexpression leads to increased invasiveness, resulting in a refractory response to chemotherapy [66,67]. Another line of evidence supporting the importance of neurotrophins in HNC has also emerged in the low-affinity TrkB co-receptor NGFR. Patient-based studies of NGFR- positive lesions had marked invasiveness and a locoregional recurrence rate 17 times greater than NGFR-negative lesions [68]. Fujii et al. also found a correlation between enhanced repressors of E-Cadherin and perineural invasion and demonstrated a significant association of perineural invasion with SIP1 and TWIST but not Snail expression [69]. These findings are intriguing and offer early clues on the specific extracellular interactions that promote invasiveness (Figure 3). Future translational studies will be required to dissect the relevance of 
Table 1 EMT biomarkers currently under evaluation in the translational setting

\begin{tabular}{|c|c|c|c|c|c|c|}
\hline Marker & Prognosis & Viral-association & $\begin{array}{l}\text { Biomarker } \\
\text { type }\end{array}$ & Study power & Concomitant markers & Reference (s) \\
\hline \multicolumn{7}{|c|}{ Classic EMT pathways implicited } \\
\hline \multirow[t]{3}{*}{ Snail 1} & \multirow{3}{*}{$\begin{array}{l}\text { Poor PFS; } \mathbf{\uparrow} \text { TNM; } \mathbf{\uparrow} \text { Metastasis; } \\
\text { Proinflammatory }\end{array}$} & \multirow[t]{3}{*}{$\mathrm{EBV}^{47}$} & $\mathrm{HC}$ & $N=147[49]$ & \multirow{3}{*}{$\begin{array}{l}\text { NBS; HIF1a (Hypoxia) E-/N } \\
\text { Cadherin (Class switching) }\end{array}$} & \multirow[t]{3}{*}{ [49-51] } \\
\hline & & & \multirow[t]{2}{*}{ In vitro } & $N=733[51]$ & & \\
\hline & & & & $N=42[50]$ & & \\
\hline \multirow[t]{2}{*}{ Snail 2 (Slug) } & \multirow[t]{2}{*}{$\mathbf{\uparrow} \mathrm{TNM} ; \mathbf{\uparrow}$ Metastasis; $\mathbf{\uparrow}$ OS } & & $\mathrm{IHC}$ & $N=119[52]$ & HIF1a & {$[52,53]$} \\
\hline & & & In vitro & & & \\
\hline \multirow[t]{3}{*}{ TWIST } & \multirow{3}{*}{$\begin{array}{l}\text { Poor PFS; } \mathbf{\uparrow} \text { Metastasis; } \uparrow \text { OS; } \\
\mathbf{\uparrow} \text { Positive Nodal status }\end{array}$} & & $\mathrm{IHC}$ & $N=147[49]$ & \multirow[t]{3}{*}{ HIF1a; Snail } & \multirow[t]{3}{*}[49,54,55]{} \\
\hline & & & In vitro & $N=109[54]$ & & \\
\hline & & & & $N=69[55]$ & & \\
\hline \multirow[t]{2}{*}{ SIP1 } & \multirow[t]{2}{*}{$\mathbf{\uparrow}$ Delayed-type neck metastasis } & & $\mathrm{IHC}$ & $N=37[56]$ & & \multirow[t]{2}{*}{ [56] } \\
\hline & & & In vitro & & & \\
\hline ZEB & - & & In vitro & - & & \\
\hline \multicolumn{7}{|c|}{ Canonical Developmental Pathways Implicated } \\
\hline Notch/Jagged/DLL4 & - & & Sequencing & $N=56[57]$ & Hes/Hey1 & {$[57]$} \\
\hline \multirow[t]{2}{*}{ Wnt/ß-Catenin } & \multirow[t]{2}{*}{-} & & $\mathrm{IHC}$ & \multirow[t]{2}{*}{$N=374[58]$} & & \multirow[t]{2}{*}[58]{} \\
\hline & & & In vitro & & & \\
\hline Shh/GLI-1 & $\mathbf{\uparrow}$ Cetuximab resistance & & In vitro & & & {$[59]$} \\
\hline \multicolumn{7}{|c|}{ Viral EMT Pathways Implicated } \\
\hline \multirow[t]{2}{*}{ Vimentin } & \multirow[t]{2}{*}{-} & \multirow[t]{2}{*}{ HPV } & $\mathrm{IHC}$ & $N=69[55]$ & TWIST1/2; Snail; Slug & \multirow[t]{2}{*}[55]{} \\
\hline & & & In vitro & & & \\
\hline \multirow[t]{2}{*}{ TGF- $\beta$} & \multirow[t]{2}{*}{-} & \multirow[t]{2}{*}{ HPV } & $\mathrm{IHC}$ & $N=140[60]$ & \multirow[t]{2}{*}{ TGFßR1/R2 } & \multirow[t]{2}{*}[60,61]{} \\
\hline & & & In vitro & $N=200[61]$ & & \\
\hline
\end{tabular}

Note: Evidence supporting ZEB1, a key EMT transcription factor, is lacking in HNC.

these diverse mechanisms and their impact on EMT and invasion in HNC.

Closing the gap between basic science and clinical relevance will likely require more direct evidence. To this end, perhaps tumor cell tracing studies conducted with gene expression analysis of primary and metastatic tissue or evaluation of circulating tumor cells might provide some resolution to this controversy.

\section{HPV, EMT, and the environment: preclinical data, translational insight}

HNC lesions arise from direct and indirect environmental exposure to known carcinogens including tobacco, alcohol, and oncogenic viruses. A majority of cases arise in older patients with substance-use and high-risk oral sexual practices.

In a study of 171 patients, tobacco use was significantly correlated with increased cervical metastasis (100\%) compared to $54 \%$ of non-users [70]. Tobacco smoke and nicotine augment EMT in HNC models [71]. The riskassociation of alcohol use and $\mathrm{HNC}$ is also well known. As most patients present with comorbid risks, emerging animal models are incorporating ethanol and tobacco exposure with high risk HPV infection [72].

The initial controversy surrounding the role of HPVinfection and transformation of the basal keratinocytes of the oral mucosae in $\mathrm{HNC}$ neoplastic transformation has largely subsided. As mentioned above, there is little clinical evidence for increased EMT in HPV-driven disease. Accordingly, gene expression profiles of HNC cancers show that markers of EMT, cell motility, invasiveness and angiogenesis predominate in HPV-negative cancers, while HPV-driven tumors are characterized primarily by alterations of the cell cycle, mitosis and proliferation [38]. However, while proliferation and cell cycle markers are virtually absent in HPV-negative cancers, HPV-positive cancers exhibit some changes related to EMT. HPVmediated transformation of human keratinocytes in vitro alters TGF $\beta$ responses in such a way as to reduce the growth-inhibitory effects of TGF $\beta$, leaving intact the EMT responses to this cytokine, therefore effectively promoting EMT. Based on these observations and on the results of gene expression profiles of $\mathrm{HNC}$, we postulate that the pronounced EMT observed in HPV-negative cancers 


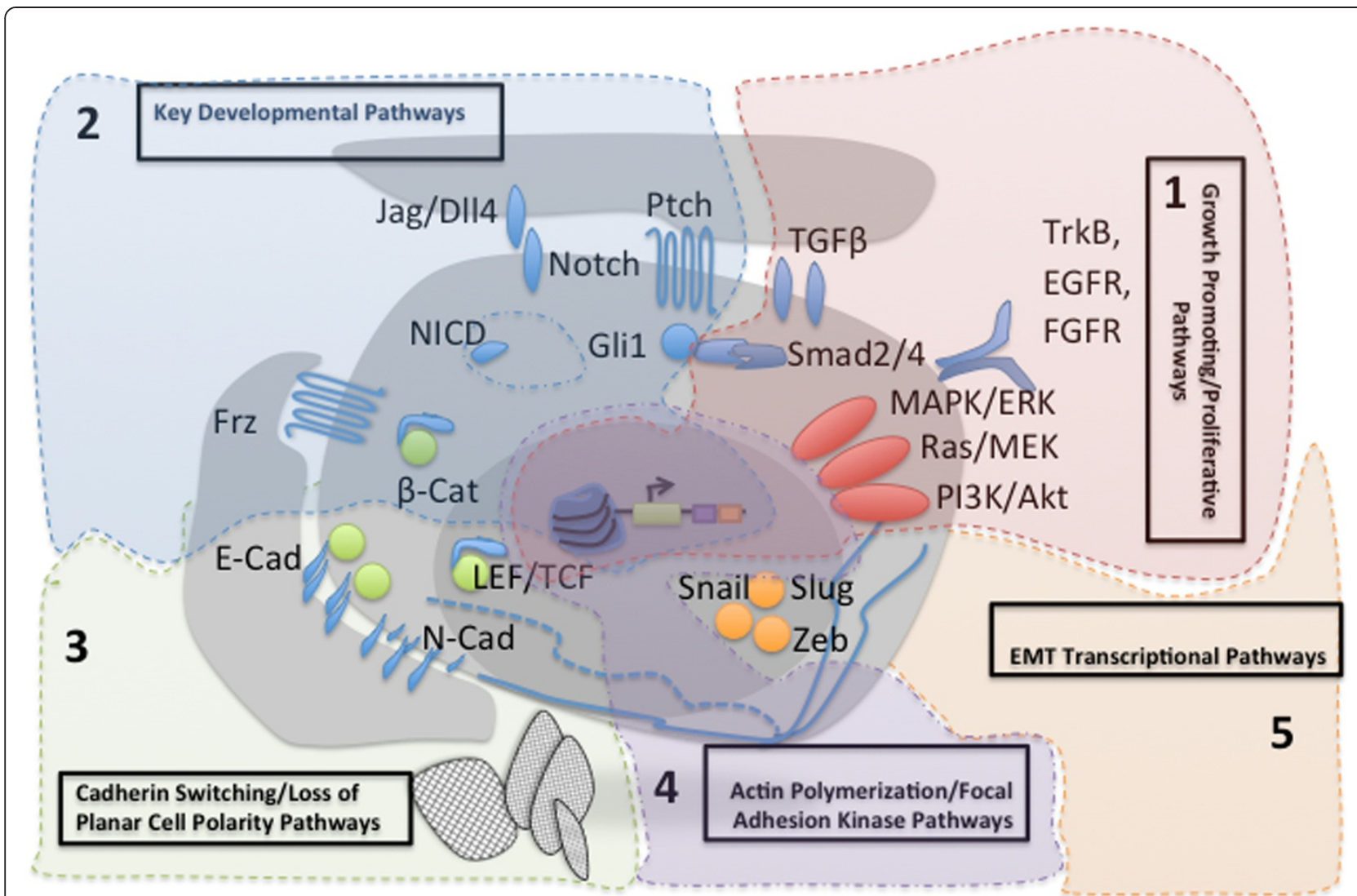

Figure 3 Known molecular EMT mechanisms can be classified into 5 major overlapping categories. 1: Growth Promoting/Proliferative Pathways are driven primarily by receptor tyrosine kinases, serine/threonine kinases, and cytokine receptors (many removed for clarity). Transforming Growth factor-beta (TGF $\beta$ ) and epidermal growth factor (EGFR) and other receptor tyrosine kinases (RTKs; For example: TrkB, Fibroblast growth factor receptor 1(FGFR1), etc.) signal via various intracellular kinases including mitogen activated kinase (p38/MAPK); Phosphoinositol-3-kinase (PI3k/Akt); and Ras-oncogene-MEK-ERK. TGF $\beta$ signaling down-stream of TGR1 and TGR1 is multifarious and can by action of phosphorylation impact multiple kinases (via the kinase Transforming Growth Factor- $\beta$-activated Kinase (TAK1)) or SMA-mothers against decapentaplegic (Smad) transcription factors. TGF $\beta$ signaling is regulated by cytoplasmic kinases (Bone Morphogenic Proteins - not discussed herein), Retinoic Acid-Retinoic Acid Receptor (RAR) and is important in developmental programs and maintaining an epithelial state. 2: Key developmental pathways are activated by kinase activity described above or morphogens (Sonic Hedgehog (Shh)-Patched(Ptch)-Gli1; Notch-Jagged(Jag)-Delta-like Ligand (DLL1/4); or Wingless (Wnt)-Frizzled (Frz)- $\beta$-catenin ( $\beta$-Cat). These canonical developmental pathways activate highly conserved transcriptional programs which center around Snail and Slug (5) in inducing epithelial to mesenchymal transition. Activation of Snail and Slug result in reduction of E-cadherin and diminution of adherens junctions and planar cell polarity PCP 3. 3: Reduced and epithelial cell adhesion with concomitant increases in N-Cadherin, loss of apico-basal orientation, and reorganization of the cytoskeleton via Rho/ROCK kinases (4, not shown) promotes cellular motility, infiltration, and lymphadenopathy. 4: Snail/Slug/Crumbs/Zeb signaling reduces PCP and increases cellular orientiation towards growth enhancing gradients ( $\mathbf{1}$; vasculature (angiogenesis; vasculogenesis) and nerves (axonogenesis; perinerual spreading and invasion). $\mathbf{5}$ : Feedback mechanisms and chromatin modifications by developmental pathways (2) perpetuate frank invasion, perineural invasion, locoregional spread, and metastasis. Not Shown: Inflammatory mediators (cytokines (Interleukins (IL) and Tumor Necrosis Factor (TNF), Chemokines (CCL and CXCR)) drive pro-inflammatory cell survival and pro-migratory pathways via hypoxia-inducible factor 1 alpha (HIF-1 a) and signal transducer and activator of transcription factor (STATs).

may be the result of mutations or permanent epigenetic changes, while in HPV-driven cancers EMT may be a dynamic response to TGF $\beta$ and/or to the overexpression of the homeobox transcription factor SIX1 [39,73-76]. Here below we discuss some of the specific observations upon which we base this hypothesis.

Highly reproducible in vitro transformation studies in keratinocytes of various origins have provided important mechanistic insight with regards to the involvement of
HPV in the transformation of human cells. We were the first to transform human foreskin keratinocytes derived from neonate donors using the HPV16 genome [77]. In the resulting model system for HPV-mediated multistep transformation of human keratinocytes (Figure 4), we demonstrated that HPV16 induces pre-neoplastic alterations that parallel many of the molecular changes detected in cervical cancer [78], therefore validating the model system as a suitable context in which to study 


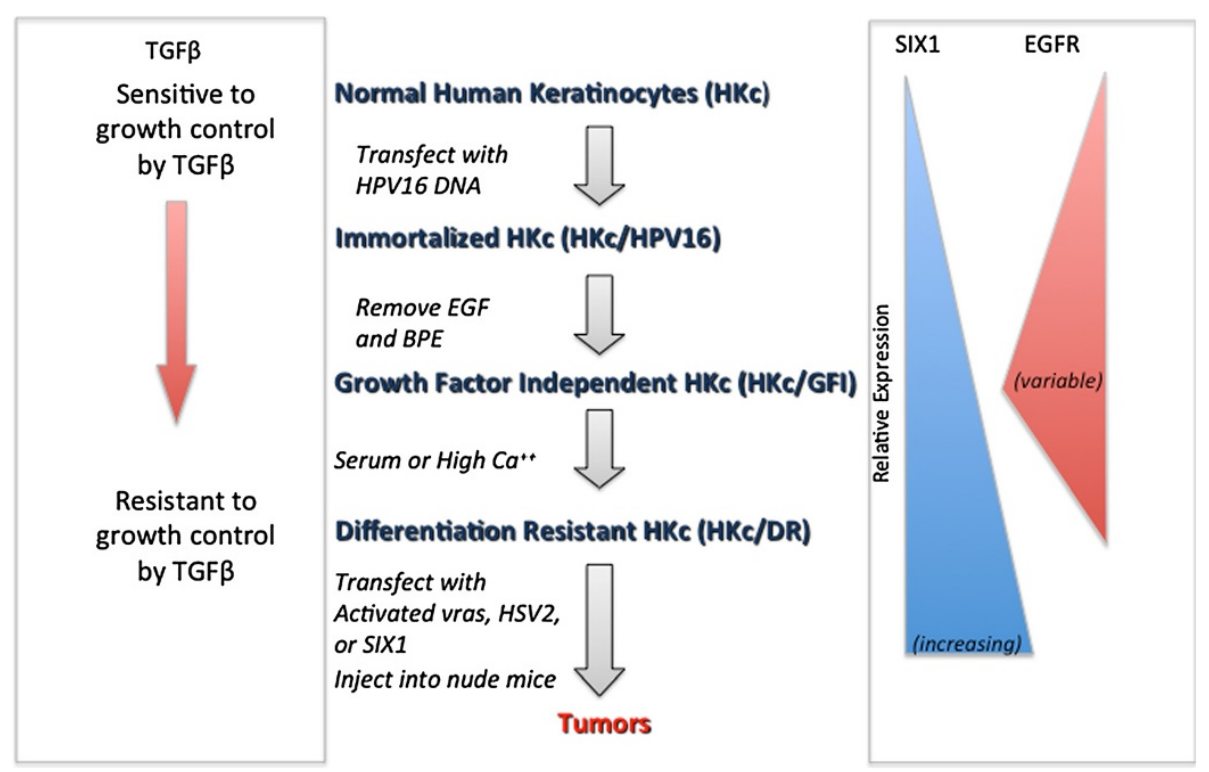

Figure 4 Emerging molecular picture from $>\mathbf{2 5}$ years of in vitro studies. Our model of keratinocyte transformation following HPV-infection, transformation, and immortalization supports intrinsic and incremental EMT changes that center around changes in TGF $\beta$, SIX1, and EGF.

molecular mechanisms of HPV-mediated immortalization and tumor progression. Our early studies demonstrated decreased sensitivity to the growth inhibitory effects of TGF $\beta$, clearly attributable to a decrease in the expression of the TGF $\beta$ receptor type I [39,73,79-81] during in vitro progression of HPV16-transformed human keratinocytes toward a pre-malignant, differentiation-resistant phenotype (Figure 4).

We and others determined that HPV16 E7 (and presumably the E7 of other oncogenic HPV types) and TGF $\beta$ exist in a dynamic balance in HPV-transformed cells: on one side, E7 interferes with TGF $\beta$ signaling by a variety of mechanisms, decreasing overall TGF $\beta$ sensitivity and contributing to a switch from Smad-mediated (growth inhibitory in human keratinocytes) to noncanonical modes of TGF $\beta$ signaling which induce EMT in human keratinocytes. On the other side, TGF $\beta$ inhibits E7 expression by a mechanism involving the activity of NF1/Ski complexes on the HPV16 upstream untranslated region (URR) which regulates the expression of the early region $[82,83]$. Hence, when canonical TGF $\beta$ signaling is robust, E7 levels are low; E7 levels rise during progression from $\mathrm{HKc} / \mathrm{HPV} 16$ to $\mathrm{HKc} / \mathrm{DR}$ and this leads to a switch in TGF $\beta$ signaling from canonical (growth inhibitory) to non-canonical (promoting EMT) [74]. More recently, we linked the switch in TGF $\beta$ signaling pathways in HPV16-transformed cells to alterations of the expression of the homeobox transcription factor SIX1, linked to invasiveness and aggressive behavior in a variety of cancers, including cervical cancer [76,78]. SIX1 mRNA and protein levels increase during progression from $\mathrm{HKc} / \mathrm{HPV} 16$ to $\mathrm{HKc} / \mathrm{DR}$ [76,78]. When overexpressed in HKc/HPV16, exogenous SIX1 induces EMT and the DR phenotype (59; Xu et al., Virology, in press). Forced overexpression of SIX1 in HKc/DR causes pronounced EMT and tumorigenicity [76]. While overexpression of SIX1 is clearly detected in a subset of cervical cancers ([78]; unpublished observations) and is linked to advanced disease when detected in any solid tumors, a role for SIX1 in HPV-driven HNC has not yet been proposed.

The changes associated with the emergence of EMT in sub-types of HNC - and specifically the role of EMT mediator TGF $\beta$ in inducing these changes - are active areas of investigation. TGF $\beta$ signaling occurs following ligand binding and heterodimerization of Type I and Type II TGF $\beta$ receptors. A diversity of feedback signaling and endogenous mediators and antagonists greatly increases the complexity of TGF $\beta$ signaling pathways. Canonical TGF $\beta$ signaling is transduced via a complex of Smad co-receptors present within the cytosol [80]. Smad2/3 are phosphorylated, recruiting Smad4 to form complexes that translocate to the nucleus where they interact with a host of co-activators and co-repressors to activate or repress the expression of target genes [80]. The switch in TGF $\beta$ responses from growth-suppressive to EMT-inducing involves a change from Smad-dependent to Smad-independent signaling [24] and appears to be a critical marker of progression in HPV-mediated HNC and EMT. In addition to SIX1 overexpression as we described above, the disabled homolog 2 (DAB2) - a recently characterized protein involved in mitogen response - might play 
a key role in regulating this switch in HNC [84]. Additionally, although not observed in mutational studies, loss of the tumor suppressor phosphatase and tensin homology (PTEN) appears to be a mechanism by which non-canonical TGF $\beta / A k t 1 / \mathrm{NF} \kappa \beta$ activation manifests in an animal model [85]. Importantly, increased mutations of PIK3CA have also been described in HPV-driven HNC suggesting a potential role for the PI3k/Akt pathway in HNC [86]. The primary HPV-16 oncogenes (E6 and E7) have also been demonstrated to up-regulate Slug, TWIST, and ZEB1/2 with marked increases in ZEB transcription factors observed [87].

The studies summarized above provide preclinical targets, which have been considered in the translational setting. While not highly represented in genome-wide studies in HNC, genetic variants in TGF $\beta 1$ have been described in a cohort of 200 serum samples from oropharyngeal squamous cell carcinoma [88]. Interestingly, while the most frequently varied alleles C509T and G915C were not significant, a 2-fold risk for more aggressive disease was significantly associated with HPV16 positive oropharyngeal lesions. These trends were most common in classically HPV-associated demographics including non-Hispanic Caucasian patients, younger age at diagnosis, never smokers and never drinkers. Moreover, frequent loss of chromosome 18q, which contains Smads 2-4 and TGRII, is observed in HNC and correlates with clinically observed invasiveness [89].

These studies have been successful in dissecting the role that HPV plays in induction of EMT and will likely drive further translational discovery.

EMT predisposing mutations in HNC: emerging genomic, epigenomic, and transcriptomic evidence

Molecular evidence for specific chromosomal aberrations, mutations, and epigenomic drivers of EMT in $\mathrm{HNC}$ has recently come to light. In addition to specific targets, these studies lend important insight to the networks driving the complex pathology observed in the HNC patient.

\section{Genomic mutations and EMT}

Several studies have demonstrated indirect mutations in important pathways relevant to EMT. Perhaps the most direct evidence comes from the recent TCGA Pan-Cancer analysis. Kandoth and colleagues characterized the presence of significant mutations in EMT-related genes and discovered mutations in multiple TGF $\beta$-related pathways (Smad4: 2\%; TGFBR2: 3\%; ACVR1B: 1.3\%; SMAD2: 1\%; ACVR2A: $0.7 \%$ of the 301 HNC tumors sampled) [90]. The study also described mutations in the histone acetyltransferase EP300 (8\%) and confirmed previous reports of mutations in Notch1 (19.3\%) being highest amongst HNC tumors $[16,90]$. Recent evidence has connected EP300 with EMT as a key transcriptional activator of E-Cadherin and the adherens complex [91]. Notch is a key activator of EMT downstream of Snail and Slug signaling [25]. Notch also activates HIF1 to promote Snail expression in response to hypoxic stress in HNC (discussed above; Table 1) [92].

\section{Epigenetics and EMT}

Epigenetic modulation of key developmental and EMTdriven pathways is another area of active translational investigation in HNC. Various studies have demonstrated epigenetic down-regulation of key epithelial molecules such as E-Cadherin. Moreover, as epigenetic sequencing technology continues to evolve, evidence has shifted to include critical roles for epigenetic regulators in the biology of HNC. Recently, it was shown that disabled homolog 2 (DAB2) - a key regulator of the TGF $\beta$-Smad signaling - is often hypermethylated resulting in aberrant TGF $\beta 2$ signaling [84]. The divergence of mutational patterns in HPVpositive lesions versus HNC-negative lesions and the presence of lesions with HPV DNA but an absence of HPV E6/E7 RNA have recently been discovered [93]. Evidence from our laboratory suggests a divergence of gene expression in these types (Tomar et al. submitted). Furthermore, consideration of the epigenetic differences in $\mathrm{HNC}$ has yielded discernable methylation patterns between $\mathrm{HPV}^{\text {dna+/rna+ }}$ versus $\mathrm{HPV}^{\text {dna+/rna- }}$ and $\mathrm{HPV}^{\text {dna-/rna- }}$ [17]. It is possible that these epigenetic sequelae preempt downstream mutations observed in $\mathrm{HNC}$ - especially when considering tobacco use. Associations between HPV-activity and specific gene expression patterns have been described in $\mathrm{HNC}$ tumors. In $\mathrm{HPV}^{\text {dna+/rna- }}$ and $\mathrm{HPV}^{\text {dna-/rna- }}$, the most up-regulated gene ontologies were key to EMT pathways and included TGF $\beta$ and $\beta$-Catenin Pathways $[38,94]$ (Figure 5).

\section{Gene expression changes and EMT}

Alteration of the expression of genes commonly associated with EMT have been directly observed in $\mathrm{HNC}$ over the past decade. First suggested by early gene expression studies, these findings are now being translated into relevant clinical associations with patientbased gene expression assays $[38,95,96]$. Walter et al. recently described a 9 gene mesenchymal subtype discovered in a validation study of 138 patients [19]. This accounted for one fifth of the entire RNA-sequenced cohort and the 9 genes that defined it were associated with EMT centering around the transcription factor TWIST, hepatocyte growth factor (HGF), and vimentin - markers of mesenchymal phenotype. While there was no statistically significant difference in survival - likely due to the small sample size per sub-type - it was suggested that these tumors might be expected to have increased locoregional metastasis. 


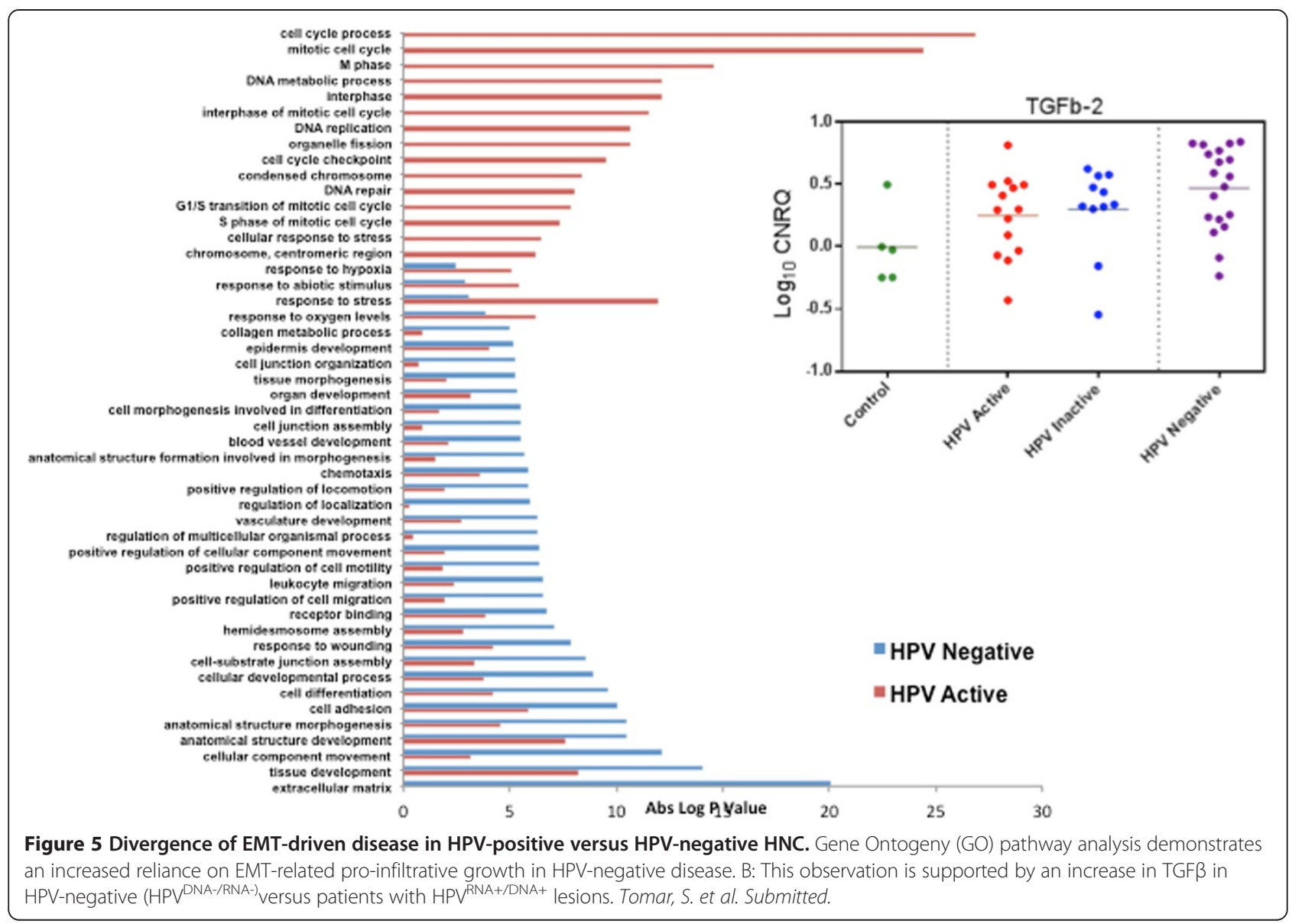

\section{MiRNAs, post-transcriptional modifications and EMT}

A great deal of interest has been focused on the involvement of neutralizing noncoding RNAs since their discovery in early 1990's [97]. Specifically, microRNAs (miRs) have attracted attention as potential therapeutic targets. It was recently suggested that the miR-200 cluster was responsible for targeted EGFR-inhibitor resistance in HNC [98]. Furthermore, a miR profile characterized by reduced miR-345 and elevated miR-1 was found to be predictive of poor metastasis-free survival in a 64 patient cohort [99]. It will be of great interest to synergize miRNA profiles with the genomic and epigenomic mutational spectrum in HNC for the identification of novel specific therapeutic targets.

Another emerging paradigm in EMT is the importance of alternative splicing in cell adhesion molecules often aberrantly expressed in invasive disease. The hyaluronic acid receptor (CD44) has gained extensive attention due to an emerging pattern of exon splicing in HNC [100]. Analysis of the dominant three isoforms CD44 v3, v6, and v10 demonstrated enhanced stage (v3 \& v6), reduced overall survival (v6 \& v10), and increased regional, distant, and perineural invasion, respectively [101]. Furthermore, laminin alpha variant 3 (LAMA3) was recently discovered to carry prognostic significance in HNC in a cohort of 59 patients [102]. This variant was validated in a cohort of $44 \mathrm{HNC}$ specimens where dystonin (DST), a plaque cell adhesion molecule, as also discovered [103]. Another splice variant, the nuclear protein 63 delta variant alpha $(\triangle \mathrm{NP} 63 \alpha)$ will also be of great translational interest given the involvement in epithelial stem cell biology and EMT $[104,105]$.

Taken together, incorporation of tissue driven molecular analysis of the sub-type specific drivers and mutational spectrum in HNC and EMT offers great translational potential. Activating mutations in PIK3CA and NOTCH1 have emerging agents (XL147, BEZ325, and GDC-0941 (PIK3CA) and OMP-52 M51 (NOTCH1) and might be potential therapeutic targets.

\section{Surrogate end-points and clinically actionable biomarkers of EMT in HNC}

The need for clinically actionable markers of locoregional invasion and metastasis at diagnosis and for prognostic markers of recurrence is pressing in HNC. Given the accessibility of the aerodigestive tract, saliva provides 
a rational matrix for assessment of these markers. Most studies to date have focused on tissue- and serum-based approaches to assess changes in EMT-related cytokines, growth factors, and genes. Classic markers of EMT (TGF $\beta$ and downstream genes Smad2/6/7 and MMP9) have been described in several studies to correlate with patient survival, locoregional invasion, and therapeutic response $[106,107]$. A recent study described TGF $\beta$ as a prognostic serum biomarker in HNC [108]. Additionally, PLAU and insulin-like growth factor binding protein 7 (IGFBP7) were found to be increased 1.5- and an impressive 35-fold, respectively, by plasma ELISA in HNC patients versus healthy volunteers [109]. Other correlations with markers of invasiveness, including matrix metalloproteinase 13 (MMP13) and MMP1, have also been detected in tissue and saliva [110]. Lallemant and colleagues, using a quantitative PCR approach in saliva, validated MMP1 as a specific marker at $100 \%$ but a low specificity of $20 \%$ [111]. Incorporation of soluble CD44 (sCD44), hyaluronic acid, and interleukin- 8 in addition to total protein was found to have a sensitivity ranging from 75 to $82.5 \%$ and a specificity of $69.2-82.1 \%$ [112]. Additional screening for the three dominant CD44 exon variants as well as those recently validated in LAMA3 and DST as described above might also yield biomarkers with clinical relevance [103]. Evaluated extensively in epithelial cell and stem cell biology in lung cancer, $\triangle \mathrm{NP} 63 \alpha$ is emerging as a predictive biomarker in $\mathrm{HNC}$ in premalignant oral preneoplastic lesions [105]. While it will be of great interest to determine the role the cancer stem-like marker CD44 and $\triangle N P 63 \alpha$ play in prognosis much remains to be elucidated regarding the overlap of these markers with EMT.

Many of these attempts to derive biomarkers are supported by isolated center-driven studies that sample a small population. These studies will invariably necessitate consortium-driven biomarker trials with the most promising of these EMT surrogate endpoints to produce the most meaningful translational benefits.

\section{Emerging potential EMT therapeutic targets in HNC}

The modern armamentarium of targeted therapies in HNC has greatly expanded with the addition of molecular-based profiling and tumor sub-typing. Currently approved molecular targeted therapy Cetuximab has added epidermal growth factor receptor (EGFR), a known EMT-inducer in $\mathrm{HNC}$, to the formulary [5]. However, the incomplete response rates of this novel therapeutic confirm the complex heterogeneity of HNC. As EMT accounts for extensive morbidity and varying therapeutic responses, several plausible targets and appealing regimens have emerged.

Strategies targeting fibroblast growth factor receptor 1 (FGFR1) via the non-selective receptor tyrosine kinase inhibitor PD173074 have provided promising preclinical results [113]. This novel strategy functionally reverses the EMT and induces a reciprocal mesenchymal-epithelial transition (MET) reducing Snail and Slug down-stream of AP-1 enhancement. This approach is made more appealing when considering that fibroblast growth factor (FGF) ligands are necessary for the maintenance of EMT phenotypes [114].

Other groups have targeted the inflammatory drivers upstream of EMT induction to achieve reduction in metastatic potential. Fujii and colleagues reported use of Cyclooxygenase-2 (COX-2) inhibitors - colecoxib, NS-398 and SC-91 - to increase E-Cadherin and reduce EMTmediators (TWIST, Snail, SIP1) [69]. Dedifferentiation strategies targeting aberrant EMT-inducing Wnt and TGF $\beta$ signaling have also been suggested in preclinical studies using patient-derived tumor stem cells. For example, and colleagues provided an interesting approach using all-transretinoic acid, an inhibitor of TGF $\beta$, and demonstrated reductions in $\beta$-Catenin and tumor growth [115].

Table 2 Currently FDA approved and preclinical therapeutic targets in the translational pipeline targeting EMT-related pathways

\begin{tabular}{|c|c|c|c|c|c|c|}
\hline Agent & Type & Target/MOA & $\begin{array}{l}\text { Combinational } \\
\text { regimen }\end{array}$ & Trial & Clinical stage & References \\
\hline Cetuximab & MAb & $\begin{array}{l}\text { EGFR-Selective Tyrosine } \\
\text { Kinase Inhibitor }\end{array}$ & $\begin{array}{l}\text { Radiation; Cisplatin } \\
\text { (Metastatic) }\end{array}$ & Bonner; EXTREME & $\begin{array}{l}\text { FDA Approved 2006; } \\
2008 \text { (Metastatic) }\end{array}$ & {$[5,119]$} \\
\hline PD173074 & Small molecule & $\begin{array}{l}\text { FGFR1; Nonselective Tyrosine } \\
\text { Kinase Inhibitor }\end{array}$ & - & - & Preclinical & [113] \\
\hline Colecoxib & Small molecule & COX-2 Inhibitor & - & - & Preclinical & [69] \\
\hline NS-398 & Small molecule & COX-2 Inhibitor & - & - & Preclinical & [69] \\
\hline SC-91 & Small molecule & COX-2 Inhibitor & - & - & Preclinical & [69] \\
\hline Trans RA & Small molecule & RAR agonist/TGF $\beta$ Antagonist & - & - & Preclinical & [115] \\
\hline AZ64 & Small molecule & $\begin{array}{l}\text { Trkß; Nonselective Tyrosine } \\
\text { Kinase Inhibitor }\end{array}$ & Cisplatin & - & Preclinical & {$[67]$} \\
\hline Bivatuzumab-DM1 & MAb & $\begin{array}{l}\text { CD44v6-Maytansionoid } \\
\text { Cytotoxin mertansine }\end{array}$ & - & - & Phase 1 (discontinued) & {$[120,121]$} \\
\hline
\end{tabular}


Direct targeting of TGF $\beta$ signaling has proven difficult in other malignancies, due to the complexity in targeting overlapping and conserved pathways that are so important for tissue and immunological homeostasis. Various biologics and RTKIs have entered clinical trials in solid malignancies but no specific HNC trials have commenced to date [116]. Another potential limitation of these trials in $\mathrm{HNC}$ comes in the form of their design as they often target late stage and recalcitrant disease. It will be of great interest to establish validated biomarkerdriven trials in HNC to assess objective responses to these multivalent therapeutic targets.

Searches for synergistic drug combinations in inflammatory and cellular signaling pathways carry immense potential for therapeutic interventions. Inhibitors of $\mathrm{NF} \kappa \beta$ (such as bortezomib) have entered clinical trials and found to be ineffective as monotherapies; however, combinatorial approaches combining targeted anti-inflammatory small molecules with RTKIs present opportunities in personalizing pharmacology to the emerging HNC sub-types [117]. Additionally, targeting strategies which incorporate targeted RTKI's with conventional chemoirradiation models offer promise in the preclinical pipeline.

To this end, studies from the Kupferman group have indicated an important role for BDNF-TrkB in chemoresistance to standard of care platinum regimen [67]. In preclinical studies, inhibition of TrkB by AZ64, a 4-amino pyrazolylpyrimidine, in combination with Cisplatin reduced tumor growth in cell line screening [118]. It will be of interest to see if other neurotrophin RTKIs currently available in the clinical pipeline hold potential as adjuvants or in combinatorial approaches [clinical trials.gov] of panreceptor inhibitors in clinical trials such as PLX7486, Lestaurtinib, TSR-01, or RXDX-101 Table 2.

Targeting of stem-like cells is another strategy that has also been explored in Phase I clinical trials. The biologic bivatuzumab-mertansine has recently been explored as an anti-stem cell agent in HNC [120]. Bivatuzumab, a CD44v6- targeting antibody conjugated with the maytansinoid cytotoxin mertansine (also known by DM1), was recently shown to be well-tolerated in a doseescalation study of 31 patients with recurrent or metastatic HNC [121]. However, despite accurate targeting of the therapeutic to $\mathrm{CD} 44$, this trial was terminated due to graded dose-related dermal toxicities.

\section{Conclusions}

EMT in Head and Neck cancers continues to attract significant translational attention. The need to synergize preclinical science with relevant pathologic staging and prognosis remains a challenge. As the basic science and molecular pathways continue to evolve, the potential promise of novel therapeutic targets and improved patient outcomes stand to be realized.

\section{Abbreviations}

EMT: Epithelial-mesenchymal transition; HNC: Head and Neck Squamous Cell Carcinoma; OS: Overall survival; HPV: Human Papilloma Virus; HKc: Human foreskin keratinocytes (HKc/HPV16 - HPV16 transformed; HKc/DR: Differentiation resistant); RTKI: Receptor tyrosine kinase inhibitors; MET: Mesenchymal-epithelial transition.

\section{Competing interests}

The authors declare that they have no competing interest related to this work, all data was accessed under IRB approval at USC School of Medicine or Wm. Jennings Dorn VAMC.

\section{Authors' contributions}

CAG, FFA, and LAP wrote and edited the manuscript. JRW edited and provided clinical insight on the manuscript. CAG composed original artwork. LAP provided final approval for submission. All authors read and approved the final manuscript. ST produced the data shown in Figure 5.

\section{Acknowledgements}

This work was supported by NIMHD \# 1P20MD001770 and VA Research Funds.

\section{Author details}

'Department of Pathology, Microbiology \& Immunology, University of South Carolina School of Medicine, Bldg. 1 Room B43 6439 Garners Ferry Rd, Columbia, SC 29208, USA. ²Department of Head and Neck Surgery, Wm. Jennings Dorn VA Medical Center, Columbia, SC 29208, USA.

Received: 20 September 2014 Accepted: 29 October 2014

Published online: 30 November 2014

\section{References}

1. Jemal A, Bray F, Center MM, Ferlay J, Ward E, Forman D: Global cancer statistics. CA Cancer J Clin 2011, 61(2):69.

2. Siegel R, Ward E, Brawley O, Jemal A: Cancer statistics, 2011: the impact of eliminating socioeconomic and racial disparities on premature cancer deaths. CA Cancer J Clin 2011, 61:212-236.

3. Chaturvedi P, Garg A, Chaturvedi U, Abbarah T, Kuwajerwala NK, Rao VUS, Gosselin BJ, Talavera F, Sadeghi N, Slack CL, Myers AD: Neck, Cervical Metastases, Surgery Workup. Medscape 2014, 849511. http://emedicine. medscape.com/article/849611.

4. Glisson B, Cango M, Feigenberg S: Head and neck tumors. In Cancer management: a multidisciplinary approach. 13th edition. Edited by Pazdur R, Wagman L, Camphausen K, Hoskins W. Manhassett: CMP Health, Media; 2011.

5. Bonner JA, Harari PM, Giralt J, Azarnia N, Shin DM, Cohen RB, Jones CU, Raben D, Jassem J, Ove R, Kies MS, Baselga J, Youssoufian H, Amellal N, Rowinsky EK, Ang KK: Radiotherapy plus cetuximab for squamous-cell carcinoma of the head and neck. NEJM 2006, 354(6):567-578.

6. Syrjänen KJ, Syrjänen SM, Lamber MA, Pyrhönen S: Human papillomavirus (HPV) involvement in squamous cell lesions of the oral cavity. Proc Finn Dent Soc 1983, 79(1):1-8.

7. Pfister H: Biology and biochemistry of papillomaviruses. Rev Physiol Biochem Pharmacol 1984, 99:111-181.

8. Hunter KD, Parkinson K, Harrison PR: Profiling early head and neck cancer. Nature Reviews Cancer 2005, 5:127-135.

9. Marur S, D'Souza G, Westra WH, Forastiere AA: HPV-associated head and neck cancer: a virus-related epidemic. Lancet Oncol 2010, 11:781-789.

10. Onon TS: History of human papillomavirus, warts, and cancer: What do we know today. Best Pract Res Clin Obstet Gyn 2011, 25:565-574.

11. Demonbreun WA, Goodpasture EW: Infectious Oral Papillomatosis of Dogs. Am J Pathol 1932, 8(1):43-56.

12. Chambers VC, Evans CA, Weiser RS: Canine Oral Papillomatosis II. Immunol Aspects Dis Cancer Res 1960, 20:1083.

13. Cubie HA: Experiments with human papillomavirus in cell culture. Br J Dermatol 1974, 91(5):569-571.

14. Pyeon D, Newton MA, Lambert PF, den Boon JA, Sengupta S, Marsit CJ, Woodworth CD, Connor JP, Haugen TH, Smith EM, Kelsey KT, Turek LP, Ahlquist P: Fundamental Differences in Cell Cycle Deregulation in Human Papillomavirus-Positive and Human Papillomavirus-negative Head/Neck and Cervical Cancers. Cancer Res 2007, 67(10):4605-4619.

15. Stransky N, Egloff AM, Tward AD, Kostic AD, Cibulskis K, Sivachenko A, Kryukov GV, Lawrence MS, Sougnez C, McKenna A, Shefler E, Ramos AH, 
Stojanov P, Carter SL, Voet D, Cortés ML, Auclair D, Berger MF, Saskena G, Guiducci C, Onofrio RC, Parkin M, Romkes M, Weissfeld JL, Seethala RR, Wang L, Rangel-Escareño C, Fernandez-Lopez JC, Hidalgo-Miranda A, Melendez-Zajdla J, Winckler W, Ardlie K, Gabriel SB, Meyerson M, Lander ES, Getz G, Golub TR, Garraway LA, Grandis JR: The mutational landscape of head and neck squamous cell carcinoma. Science 2011, 333(6046):1157-1160.

16. Agrawal N, Frederick MJ, Pickering CR, Bettegowda C, Chang K, Li RJ, Fakhry C, Xie TX, Zhang J, Wang J, Zhang N, El-Nagger AK, Jasser SA, Weinstein JN, Treviño L, Drummond JA, Muzny DM, Wu Y, Wood LD, Hruban RH, Westra WH Koch WM, Califano JA, Gibbs RA, Sidransky D, Vogelstein B, Velculescu VE, Padadopoulos N, Wheeler DA, Kinzler KW, Myers JN: Exome sequencing of head and neck squamous cell carcinoma reveals inactivating mutations in NOTCH1. Science 2011, 333(6046):1154-1170.

17. Kostareli E, Hozlinger D, Bogatyrova O, Hielscher T, Wichmann G, Keck M, Lahrmann B, Grabe N, Flechtenmacher C, Schmidt CR, Seiwert T, Dyckhoff G, Dietz A, Höfler D, Pawlita M, Benner A, Bosch FX, Plinkert P, Plass C, Weichenhan D, Hess J: HPV-related methylation signature predicts survival in oropharyngeal squamous cell carcinomas. J Clin Invest 2013, 123(6):2488-2501

18. Tamborero D, Gonzalez-Perez A, Perez-Llamas C, Deu-Pons J, Kandoth C, Reimand J, Lawrence MS, Getz G, Bader GD, Ding L, Lopez-Bigas N: Comprehensive identification of mutational cancer driver genes across 12 tumor types. Scientific Rep 2013, 3:2650. doi:10.1038/srep02650.

19. Walter V, Yin X, Wilkerson MD, Cabanski CR, Zhao N, Du Y, Ang MK, Hayward MC, Salazar AH, Hoadley KA, Fritchie K, Sailey CJ, Weissler MC, Shockley WW, Zanation AM, Hackman T, Thorne LB, Funkhouser WD, Muldrew KL, Olshan AF, Randell SH, Wright FA, Shores CG, Hayes DN: Molecular Subtypes in Head and Neck Cancer Exhibit Distinct Patterns of Chromosomal Gain and Loss of Canonical Cancer Genes. PLoS ONE 2013, doi:10.1371/annotation/e9ad5950-a048-4a44-8e26-d8b07a9d4bb8.

20. Greenburg G, Hay ED: Epithelia suspended in collagen gels can lose polarity and express characteristics of migrating mesenchymal cells. J Cell Biol 1982, 95:333-339.

21. Kalluri $R$, Weinberg RA: The basics of epithelial-mesenchymal transition. $J C l$ 2009, 119(6):1420-1428.

22. Wu C-Y, Tasi Y-P, Wu M-Z, Teng S-C, Wu K-J: Epigenetic reprogramming and post-transcriptional regulation during the epithelial-mesenchymal transition. Trends Genetics 2012, 28(9):454-463.

23. Theiry JP: Epithelial-mesenchymal transitions in tumor progression. Nat Rev Can 2002, 2:442-454

24. Massague J: TGF $\beta$ Signaling in context. Nat Rev Mol Cell Biol 2012, 13:616-630.

25. Lamouille S, XU J, Derynck R: Molecular mechanisms of epithelialmesenchymal transition. Nat Rev Mol Cell Biol 2014, 15:178-196.

26. Leethanakul C, Patel V, Gillespie J, Pallente M, Ensley JF, Koontongkaew S, Liotta LA, Emmert-Buck M, Gutkind JS: Distinct pattern of expression of differentiation and growth related-genes in squamous cell carcinomas of the head and neck revealed by use of laser capture microdissection and cDNA arrays. Oncogene 2000, 19:3220-3224.

27. Yang F, Zeng Q, Yu G, Li S, Wang CY: Wnt/beta-catenin signaling inhibits death receptor-mediated apoptosis and promotes invasive growth of HNSCC. Cell Signal 2006, 18(5):679-687.

28. Díaz Prado SM, Medina Villaami V, Aparicio Gallego G, Blanco Calvo M, López C, Sironvalle Soliva S, Valladares Ayerbes M, García Campelo R, Antón Aparicio LM: Expression of Wnt gene family and frizzled receptors in head and neck squamous cell carcinomas. Virchows Arch 2009, 455(1):67-75.

29. Katase N, Lefeuvre M, Gunduz M, Beder LB, Grenman R, Fujii M, Tamamura R Tsujigiwa H, Nagatsuka H: Absence of Dickkopf (DKK)-3 protein expression is correlated with longer disease-free survival and lower incidence of metastasis in head and neck squamous cell carcinoma. Oncol Lett 2012, 3(2):273-280.

30. Marsit CJ, McClean MD, Furniss CS, Kelsey KT: Epigenetic inactivation of the SFRP genes is associated with drinking, smoking, and HPV in head and neck squamous cell carcinoma. Int J Cancer 2006, 119(8):1761-1766.

31. Paluszczak J, Hemmerling D, Kostrzewska-Poczekaj M, Jarmuż-Szymczak M, Grenman R, Wierzbicka M, Baer-Dubowska W: Frequent hypermethylation of WNT pathway genes in laryngeal squamous cell carcinomas. J Oral Pathol Med 2014, doi:10.1111/jop.12178.

32. Mattox DE, Von Hoff DD: In vitro stem cell assay in head and neck squamous carcinoma. Am J Surg 1980, 140(4):527-530.
33. Mattox DE, Von Hoff DD: Culture of human head and neck cancer stem cells using soft agar. Arch Otolaryngol 1980, 106(11):672-674.

34. Braakhuis BJM, Leemans $C R$, Brakenhoff RH: A genetic progression model of oral cancer: current evidence and clinical implications. J Oral Pathol Med 2004, 33:317-322.

35. Zhang F, Filho MS, Nör JE: The biology of head and neck cancer stem cells. Oral Oncol 2012, 48(1):1-9.

36. Chiou S-H, Yu C-C, Huang C-Y, Lin S-C, Liu C-J, Tsai T-H, Chou S-H, Chien C-S, Ku H-H, Lo J-F: Positive Correlations of Oct-4 and Nanog in Oral Cancer Stem-Like Cells and High Grade Oral Squamous Cell Carcinoma. Clin Cancer Res 2008, 14:4085-4095.

37. Tarin D, Thompson DW, Newgreen DF: The fallacy of epithelial mesenchymal transition in neoplasia. Can Res 2005, 65(14):5996-6000.

38. Chung CH, Parker JS, Ely K, Carter J, Yi Y, Murphy BA, Ang KK, El-Naggar AK, Zanation AM, Cmelak AJ, Levy S, Slebos RJ, Yarrough WG: Gene expression profiles identify epithelial-to-mesenchymal transition and nuclear factor kappaB signaling as characteristics of a high-risk head and neck squamous cell carcinoma. Cancer Res 2006, 66(16):8210-8218.

39. Mi Y, Borger DR, Fernandes PR, Pirisi L, Creek KE: Loss of transforming growth factor-beta (TGF-beta) receptor type I mediates TGF-beta resistance in human papillomavirus type 16-transformed human keratinocytes at late stages of in vitro progression. Virology 2000, 270(2):408-416.

40. Jemal A, Siegel R, Ward E, Murray T, Xu J, Thun MJ: Cancer Statistics, 2007. CA Cancer J Clin 2007, 57(1):43-66.

41. Slaughter DP, Southwick HW, Smejkal W: Field cancerization in oral stratified squamous epithelium; clinical implications of multicentric origin. Cancer 1953, 6(5):963-968.

42. Braakhuis BJ, Tabor MP, Kummer JA, Leemans CR, Brakenhoff RH: A Genetic Explanation of Slaughter's Concept of Field Cancerization: Evidence and Clinical Implications. Can Res 2003, 63(8):1727-1730.

43. Boscolo-Rizzo P, Del Mistro A, Bussu F, Lupato V, Baboci L, Almadori G, Da Mosto MC, Paludetti G: New insights into human papillomavirusassociated head and neck squamous cell carcinoma. Acta Otorhinolaryngol Ital 2013, 33:77-87.

44. Baumeister P, Reiter M, Welz C, Becker S, Betz C, Harréus U: Surgically treated oropharyngeal cancer: risk factors and tumor characteristics. J Cancer Res Clin Oncol 2014 140(6):1011-1019.

45. Murray SA, Gridley T: Snail family genes are required for left- right asymmetry determination, but not neural crest formation, in mice. Proc Natl Acad Sci 2006, 103:10300-10304.

46. Arnoux V, Nassour M, L'Helgoualc'h A, Hipskind RA, Savagner P: Erk5 controls slug expression and keratinocyte activation during wound healing. Mol Biol Cell 2008, 19:4738-4749.

47. Smith A, Teknos TN, Pan Q: Epithelial to mesenchymal transition in head and neck squamous cell carcinoma. Oral Oncol 2013, 49(4):287-292.

48. Perl AK, Wilgenbus P, Dahl U, Semb H, Christofori G: A causal role for E-cadherin in the transition from adenoma to carcinoma. Nature 1998 392:190-193.

49. Yang MH, Chang SY, Chiou SH, Liu CJ, Chi CW, Chen PM, Teng SCWKJ: Overexpression of NBS1 induces epithelial-mesenchymal transition co-expression of NBS1 and Snail predicts metastasis of head and neck cancer. Oncogene 2007, 26(10):1459-1467.

50. Yang MH, Wu MZ, Chiou SH, Chen PM, Chang SY, Liu CJ, Teng SC, Wu KJ: Direct regulation of TWIST by HIF-1alpha promotes metastasis. Nat Cell Biol 2008, 10(3):295-305.

51. St. John MA, Dohadwala M, Luo J, Wang G, Lee G, Shih H, Heinrich E, Krysan K, Walser T, Hazra S, Zhu L, Lai C, Abemayor E, Fishbein M, Elashoff DA, Sharma S, Dubinett SM: Proinflammatory mediators upregulate snail in head and neck squamous cell carcinoma. Clin Cancer Res 2009, 15(19):6018-6027.

52. Zhang J, Cheng Q, Zhou Y, Wang Y, Chen X: Slug is a key mediator of hypoxia induced cadherin switch in HNSCC: correlations with poor prognosis. Oral Oncol 2013, 49(11):1043-1050.

53. Kojc N, Zidar N, Gale N, Poljak M, Fujs Komlos K, Cardesa A, Hofler H, Becker KF: Transcription factors Snail, Slug, Twist, and SIP1 in spindle cell carcinoma. Virchows Arch 2009, 454(5):549-555.

54. Jouppila-Mättö A, Närkiö-Mäkelä M, Soini Y, Pukkila M, Sironen R, Tuhkanen $H$, Mannermaa A, Kosma VM: Twist and snai1 expression in pharyngeal squamous cell carcinoma stroma is related to cancer progression. BMC Cancer 2011, 11(11):350. 
55. Gasparatto D, Polesel J, Marzotto A, Colladel R, Piccinin S, Modena P, Grizzo A, Sulfaro S, Serraino D, Barzan L, Doglioni C, Maestro R: Overexpression of TWIST2 correlates with poor prognosis in Head and Neck Squamous Cell Carcinomas. Oncotarget 2011, 2(12):1165-1175.

56. Sakamoto K, Imanishi Y, Tomita T, Shimoda M, Kameyama K, Shibata K, Sakai N, Ozawa H, Shigetomi S, Fujii R, Fujii M, Ogawa K: Overexpression of SIP1 and downregulation of E-cadherin predict delayed neck metastasis in stage $1 / /$ oral tongue squamous cell carcinoma after partial glossectomy. Ann Surg Oncol 2012, 19(2):612-619.

57. Sun W, Gaykalova DA, Ochs MF, Mambo E, Arnaoutakis D, Liu Y, Loyo M, Agrawal N, Howard J, Li R, Ahn S, Fertig E, Sidransky D, Houghton J, Buddavarapu K, Sanford T, Choudhary A, Darden W, Adai A, Latham G, Bishop J, Sharma R, Westra WH, Hennessey P, Chung CH, Califano JA: Activation of the NOTCH pathway in Head and Neck Cancer. Cancer Res 2014, 74:1091-1104.

58. Santoro A, Pannone G, Papagerakis S, McGuff HS, Cafarelli B, Lepore S, De Maria S, Rubini C, Mattoni M, Staibano S, Mezza E, De Rossa G, Aquino G, Losito S, Loreto C, Crimi S, Bufo P, Lo Muzio L: Beta-catenin and epithelial tumors: a study based on 374 oropharyngeal cancers. Biomed Res Int 2014, 948264. doi: 10.1155/2014/948264.

59. Keysar SB, Le PN, Anderson RT, Morton JJ, Bowles DW, Paylor JJ, Vogler BW, Thorburn J, Fernandez P, Glogowska MJ, Takimoto SM, Sehrt DB, Gan GN, Eagles-Soukup JR, Serracino H, Hirsch FR, Lucia MS, Thorburn A, Song J: Hedgehog Signaling Alters Reliance on EGF Receptor Signaling and Mediates Anti-EGFR Therapeutic Resistance in Head and Neck Cancer. Cancer Res 2013, 73:3381-3392.

60. Logullo AF, Nonogaki S, Miguel RE, Kowalski LP, Nishimoto IN, Pasini FS, Federico MH, Brentani RR, Brentani MM: Transforming growth factor beta1 (TGFbeta1) expression in head and neck squamous cell carcinoma patients as related to prognosis. J Oral Pathol Med 2003, 32(3):139-145.

61. Guan X, Sturgis EM, Lei D, Liu Z, Dahlstrom KR, Wei Q, Li G: Association of TGF-beta1 1 with HPV16-positive oropharyngeal cancer. Clin Cancer Res 2010, 16(5):1416-14122.

62. Mendelsohn AH, Lai CK, Shitaku IP, Fishbein MC, Brugman K, Elashoff DA, Abemayor E, Dubinett SM, St. John MA: Snail as a novel marker for regional metastasis in head and neck squamous cell carcinoma. Am J Otolaryngol 2012, 33(1):6-13.

63. Häyry V, Mäkinen LK, Atula T, Sariola H, Mäkitie A, Leivo I, Keski- Säntti H, Lundin J, Haglund C, Hagström J: Bmi-1 expression predicts prognosis in squamous cell carcinoma of the tongue. $\mathrm{Br} J$ Cancer 2010, 102(5):892-897

64. Horikawa T, Yoshizaki T, Kondo S, Furukawa M, Kaizaki Y, Pagano JS: Epstein-Barr Virus latent membrane protein 1 induces Snail and epithelial-mesenchymal transition in metastastic nasopharyngeal carcinoma. Br J Cancer 2011, 104(7):1160-1167.

65. Zhu L, Werner JA, Mandic R: Implications of Tropomyosin-related kinase B (TrkB) in head and neck cancer. Anticancer Res 2007, 27(5A):3121-3126.

66. Kupferman ME, Jiffar T, El-Naggar A, Yilmaz T, Zhou G, Xie T, Feng L, Wang J, Holsinger FC, Yu D, Myers JN: TrkB induces EMT and has a key role in invasion of head and neck squamous cell carcinoma. Oncogene 2010, 29:2047-2059.

67. Lee J, Jiffar T, Kupferman ME: A novel role for BDNF-TrkB in the regulation of chemotherapy resistance in head and neck squamous cell carcinoma. PLOS ONE 2012, 7(1):e30246.

68. Søland TM, Brusevold IJ, Koppang HS, Schenck K, Byrne M: Nerve growth factor receptor (p75 NTR) and pattern of invasion predict poor prognosis in squamous cell carcinoma. Histopathology 2008, 53(1):62-72.

69. Fujii R, Imanishi Y, Shibata K, Sakai N, Sakamoto, Shigetomi S, Habu N, Otsuka K, Sato Y, Wantabe Y, Ozawa H, Tomita T, Kameyama K, Fujii M, Ogawa K: Restoration of E-cadherin expression by selective Cox-2 inhibition and the clinical relevance of epithelial-to-mesenchymal transition in head and neck squamous cell carcinoma. J Exp Clin Cancer Res 2014, 33(1):40.

70. Mansour Ol, Synderman CH, D'Amico F: Association between tobacco use and metastatic neck disease. Laryngoscope 2003, 113(1):161-166.

71. Yu MA, Kiang A, Wang-Rodriguez J, Rahimy E, Haas M, Yu V, Ellies LG, Chen J, Fan JB, Brumund KT, Weisman RA, Ongkeko WM: Nicotine promotes acquisition of stem cell and epithelial-to-mesenchymal properties in head and neck squamous cell carcinoma. PLOS ONE 2012, 7(12):e51967. doi: 10.1371
72. Chamuilitrat W, Schmidt R, Chunglok W, Kohl A, Tomakidi P: Epithelium and fibroblast-like phenotypes derived from HPV16 E6/E7-immortalized human gingival keratinocytes following chronic ethanol treatment. Eur J Cell Biol 2003, 82(6):313-322.

73. Borger DR, Mi Y, Geslani G, Zyzak LL, Batova A, Engin TS, Pirisi L, Creek KE: Retinoic acid resistance at late stages of human papillomavirus type 16-mediated transformation of human keratinocytes arises despite intact retinoid signaling and is due to a loss of sensitivity to transforming growth factor-beta. Virology 2000, 270(2):397-407.

74. Kowli S, Velidandla R, Creek KE, Pirisi L: TGF- $\beta$ regulation of gene expression at early and late stages of HPV16-mediated transformation of human keratinocytes. Virology 2013, 447(1-2):63-73.

75. Altomare D, Velidandla R, Pirisi L, Creek KE: Partial loss of Smad signaling during in vitro progression of HPV16-immortalized human keratinocytes. BMC Cancer 2013, 13:424

76. Xu H, Zhang Y, Altomare D, Peña MM, Wan F, Pirisi L, Creek KE: Six1 promotes epithelial-mesenchymal transition and malignant conversion in human papillomavirus type-16 immortalized human keratinocytes. Carcinogenesis 2014, 35(6):1379-1388.

77. Pirisi L, Yasumoto S, Feller M, Doniger, DiPaolo JA: Transformation of human fibroblasts and keratinocytes with human papillomavirus type 16 DNA. J Virol 1987, 61(4):1061-1066.

78. Wan F, Miao X, Quraishi I, Kennedy V, Creek KE, Pirisi L: Gene expression changes during HPV-mediated carcinogenesis: a comparison between an in vitro cell model and cervical cancer. Int J Cancer 2008, 123(1):32-40.

79. Batova A, Danielpour D, Pirisi L, Creek KE: Retinoic acid induces secretion of latent transforming growth factor beta 1 and beta 2 in normal and human papillomavirus type 16-immortalized human keratinocytes. Cell Growth Differ 1992, 3(11):763-772.

80. Creek KE, Geslani G, Batova A, Pirisi L: Progressive loss of sensitivity to growth control by retinoic acid and transforming growth factor beta at late stages of human papillomavirus type 16-initiated transformation of human keratinocytes. Adv Exp Med Biol 1995, 375:117-135

81. Hypes MK, Pirisi L, Creek KE: Mechanisms of decreased expression of transforming growth factor-beta receptor type I at late stages of HPV16-mediated transformation. Cancer Lett 2009, 282(2):177-186.

82. Baldwin A, Pirisi L, Creek KE: NFI-Ski interactions mediate transforming growth factor beta modulation of human papillomavirus type 16 early gene expression. J Virol 2004, 78(8):3953-3964.

83. Baldwin A, Hypes MK, Pirisi L, Creek KE: NFI is an essential positive transcription factor for human papillomavirus type 16 early gene expression. Open Virol 2007, 1:33-38.

84. Hannigan A, Smith P, Kalna G, Lo Nigro C, Orange C, O'Brien DI, Shah R, Syed N, Spender LC, Herrera B, Thurlow JK, Lattanzio L, Monteverde M, Maurer E, Buffa FM, Mann J, Chu DC, West CM, Partridge M, Oien KA, Cooper JA, Frame MC, Harris AL, Hiller L, Nicholson LJ, Gasco M, Crook T, Inman GJ: Epigenetic downregulation of human disabled homolog 2 switches TGF-beta from a tumor suppressor to a tumor promoter. $J$ Clin Invest 2010, 120(8):2842-2857.

85. Bian Y, Hall B, Sun ZJ, Molinolo A, Chen W, Gutkind JS, Waes CV, Kulkarni AB: Loss of TGF- $\beta$ signaling and PTEN promotes head and neck squamous cell carcinoma through cellular senescence evasion and cancer-related inflammation. Oncogene 2012, 31(28):3322-3332.

86. Sewell A, Brown B, Biktasova A, Mills GB, Lu Y, Tyson DR, Issaeva N, Yarbrough WG: Reverse-phase protein array profiling of oropharyngeal cancer and significance of PIK3CA mutations in HPV-associated head and neck cancer. Clin Cancer Res 2014, 20(9):2300-2311.

87. Jung YS, Kato I, Kim HR: A novel function of HPV16-E6/E7 in epithelial-mesenchymal transition. Biochem Biophys Res Commun 2013, 435(3):339-344.

88. Guan X, Sturgis EM, Lei D, Liu Z, Dahlstrom KR, Wei Q, Li G: Association of TGF-beta1 genetic variants with HPV16-positive oropharyngeal cancer. Clin Cancer Res 2010, 16(5):1416-1422.

89. Leemans $C R$, Braakhuis BJ, Brakenhoff $\mathrm{RH}$ : The molecular biology of head and neck cancer. Nat Rev Cancer 2011, 11(1):9-22.

90. Kandoth C, McLellan MD, Vandin F, Ye K, Niu B, Lu C, Xie M, Zhang Q, McMichael JF, Wyczalkowski MA, Leiserson MDM, Miller CA, Welch JS, Walter MJ, Wendl MC, Ley TJ, Wilson RK, Raphael BJ, Ding L: Mutational landscape and significance across 12 major cancer types. Nature 2013, 502:333-339.

91. Zhou Y, Hu Y, Yang M, Jat P, Li K, Lombardo Y, Xiong D, Coombes RC, Raguz S, Yagüe E: The miR-106b 25 cluster promotes bypass of 
doxorubicin-induced senescence and increase in motility and invasion by targeting the E-cadherin transcriptional activator EP300. Cell Death Differ 2014, 21(3):462-474.

92. Sahlgren C, Gustafsson MV, Jin S, Poellinger L, Lendahl U: Notch signaling mediates hypoxia-induced tumor cell migration and invasion. PNAS 2008, 105:6392-6397.

93. Weinberger PM, Merkley MA, Khichi SS, Lee JR, Psyrri A, Jackson LL, Dynan WS: Human papillomavirus-active head and neck cancer and ethnic health disparities. Laryngoscope 2010, 120(8):1531-1537.

94. White RA, Malkoski SP, Wang W-J: TGF $\beta$ in head and neck squamous cell carcinoma. Oncogene 2010, 29:5437-5446.

95. Blebin TJ, Singh B, Barber I, Socci N, Wenig B, Smith R, Prystowsky MB, Childs G: Molecular Classification of Head and Neck Squamous Cell Carcinoma Using cDNA Microarrays. Cancer Res 2002, 62:1184-1190.

96. Ginos MA, Page GP, Michalowciz BS, Patel KJ, Volker SE, Pambuccian SE, Ondey FG, Adams GL, Gaffney PM: Indentification of a Gene Expression Signature Associated with Recurrent Disease in Squamous cell Carcinoma of Head and Neck. Cancer Res 2004, 64:55-63.

97. Lee RC, Feinbaum RL, Ambros V: The C. elegans heterochronic gene lin-4 encodes small RNAs with antisense complementarity to lin14. Cell 1993, 75(5):843-854

98. Izumchenko E, Chang X, Michailidi C, Kagohara L, Ravi R, Paz K, Brait M, Hoque M, Ling S, Bedi A, Sidransky D: The TGF $\beta$-miR200-MIG6 pathway orchestrates the EMT-associated kinase switch that induces resistance to EGFR inhibitors. Can Res 2014, 74(14):3995-4005.

99. Jung AC, Job S, Ledrappier S, Macabre C, Abecassis J, de Reyniès A, Wasylyk B: A poor prognosis subtype of HNSCC is consistently observed across methylome, transcriptome, and miRNome analysis. Clin Cancer Res 2013, 19(15):4174-4184

100. Herold-Mende C, Seiter S, Born Al, Patzelt E, Schupp M, Zöller J, Bosch FX, Zöller M: Expression of CD44 splice variants in squamous epithelia and squamous cell carcinomas of the head and neck. J Pathol 1996, 179(1):66-73.

101. Wang SJ, Wong G, de Heer AM, Xia W, Bourguignon LY: CD44 variant isoforms in head and neck squamous cell carcinoma progression. Laryngoscope 2009, 119(8):1518-1530.

102. Moller-Levet CS, Betts GN, Harris AL, Homer JJ, West CM, Miller CJ: Exon array analysis of head and neck cancers identifies a hypoxia related splice variant of LAMA3 associated with poor prognosis. PLOS Comput Biol 2009, 5(11):e1000571.

103. Li R, Ochs MF, Ahn SM, Hennessey P, Tan M, Soudry E, Gaykalova DA, Uemura M, Brait M, Shao C, Westra W, Biship J, Fertig EJ, Califano JA: Expression microarray analysis revelas alternative splicing of LAMA3 and DST genes in head and neck squamous cell carcinoma. PLOS ONE 2014, 9(3):e91263. doi:10.1371.

104. Higashikawa K, Yoneda S, Tobiume K, Taki M, Shigeishi H, Kamata N: Snail-induced down-regulation of DeltaNp63alpha acquires invasive phenotype of human squamous cell carcinoma. Can Res 2007, 67(19):9207-9213.

105. Saintigny P, El-Naggar AK, Papadimitrakopoulou V, Ren H, Fan YH, Feng J, Lee JJ, Kim ES, Hong WK, Lippman SM, Mao L: DeltaNp63 overexpression, alone and in combination with other biomarkers, predicts the development of oral cancer in patients with leukoplakia. Clin Cancer Res 2009, 15(19):6284-6291.

106. Elahi M, Rakhshan V, Ghasemian NT, Moshref M: Prognostic value of transforming growth factor beta 1 [TGF- $\beta 1$ ] and matrix metalloproteinase 9 [MMP9] in oral squamous cell carcinoma. Biomarkers 2012, 17(1):21-27.

107. Mangone FR, Walder F, Maistro S, Pasini FS, Lehn CN, Carvalho MB, Brntani MM, Snitcovsky I, Frederico MH: Smad2 and Smad6 as predictors of overall survival in oral squamous cell carcinoma patients. Mol Cancer 2010, 9:106.

108. Chang PY, Kuo YB, Wu TL, Liao CT, Sun YC, Yen TC, Chan EC: Association and prognostic value of serum inflammation markers in patients with leukoplakia or oral cavity cancer. Clin Chem Lab Med 2013, 51(6):1291-1300

109. Sepiashvili L, Hui A, Ignatchenko V, Shi W, Su S, Xu W, Huang SH, O'Suillivan B, Waldron J, Irish JC, Perez-Ordonez B, Liu F-F, Kislinger T: Potentially novel candidate biomarkers for Head and Neck Squamous Cell Carcinoma Identified Using an Integrated Cell Line-based Discovery Strategy. Mol Cell Proteomics 2012, 11(11):1404-1415
110. Marcos CA, Martínez DA, de Los Toyos JR, Domíguez Iglesias F, Hermsen M, Guervós MA, Pendás $\mathrm{J}$ : The usefulness of new serum tumor markers in head and neck squamous cell carcinoma. Otolarygnol Head Neck Surg 2009, 140(3):375-380.

111. Lallemant B, Evrard A, Combescure C, Chapuis H, Chambon G, Raynal C, Reyanud C, Sabra O, Joubert D, Hollande F, Lallemant JG, Lumbroso S, Brouillet JP: Clinical relevance of nine transcriptional molecular markers for the diagnosis of head and neck squamous carcinoma in tissue and saliva rinse. BMC Cancer 2009, 18(9):370.

112. Lutécia H, Pereira M, Adebisi IN, Perez A, Wiebel M, Reis I, Duncan R, Goodwin WJ, Hu JJ, Lokeshwar VB, Franzmann EJ: Salivary markers and risk factor data: A multivariate modeling approach for head and neck squamous cell carcinoma detection. Cancer Biomarkers 2012, 10(5):241-248.

113. Nguyen PT, Tsunematsu T, Yanagisawa S, Kudo Y, Miyauchi M, Kamata N, Takeda T: The FGFR1 inhibitor PD173074 induces mesenchymalepithelial transition through transcription factor AP-1. Br J Cancer 2013, 109(8):2248-2258

114. Billottet C, Tuefferd M, Gentien D, Rapinat A, Thiery JP: Broet P, and Jouanneau, J: Modulation of several waves of gene expression during FGF-1 induced epithelial-mesenchymal transition of carcinoma cells. J Cell Biochem 2008, 104:826-839.

115. Lim YC, Kang HJ, Kim YS, Choi EC: All-trans-retinoic acid inhibits growth of head and neck cancer stem cells by suppression of Wnt/ $\beta$-Catenin pathway. Eur J Cancer 2012, 48(17):3310-3318.

116. Akhurst RJ, Hata A: Targeting the TGF $\beta$ signaling pathway in disease. Nat Rev Drug Discov 2012, 11:790-811.

117. Glibert J, Lee JW, Argiris A, Haigentz M Jr, Feldman LE, Jang M, Arun P, Van Waes C, Forastiere AA: Phase II 2-arm trial of the protesome inhibitor, PS-341 (bortezomib) in combination with irinotecan or PS-341 alone followed by the addition of irnotecan at time of progression in patients with locally recurrent or metastatic squamous cell carcinoma of the head and neck (E1304): a trial of the Eastern Cooperative Oncology Group. Head Neck 2013, 35(7):942-948.

118. Yilmaz T, Jiffar T, de la Garza G, Lin H, Milas Z, Takahashi Y, Hanna E, Maclntyre T, Brown JL, Myers JN, Kupferman ME: Therapeutic targeting of Trk suppressor tumor proliferation and enhances cisplatin activity in HNSCC. Cancer Biol Ther 2010, 10(6):644-653.

119. Vermorken JB, Mesia R, Rivera F, Remenar E, Kawecki A, Rottey S, Erfan J, Zabolotnyy D, Kienzer HR, Cupissol D, Peyrade F, Benasso M, Vynnychenko I, De Raucort D, Bokemeyer C, Schueler A, Amellal N, Hitt R: Platinum-based chemotherapy plus cetuximab in head and neck cancer. NEJM 2008, 359(11):1116-1127.

120. Tijink BM, Butler J, De Bree R, Giaccone G, Lang MS, Staab A, Leemans CR, Van Dongen GA: A Phase I dose escalation study with anti-CD44c6 bivatuzumab mertansine in patients with incurable squamous cell carcinoma of the head and neck or esophagus. Clin Cancer Res 2006, 12(20):6064-6072.

121. Riechelmann H, Sauter A, Golze W, Hanft G, Schroen C, Hoermann K, Erhardt T, Gronau S: Phase I trial with the CD44v6-targeting immunoconjugate bivatuzumab mertansine in head and neck squamous cell carcinoma. Oral Oncol 2008, 44(9):823-829.

\section{doi:10.1186/s40169-014-0039-9}

Cite this article as: Graves et al:: The translational significance of epithelial-mesenchymal transition in head and neck cancer. Clinical and Translational Medicine 2014 3:39. 